Please do not remove this page

RMIT

UNIVERSITY

\title{
Ned Kelly, John Barry and the role of social activism in criminal justice reform: Excerpts from the 2010 John Barry memorial lecture
}

Norden, Peter

https://researchrepository.rmit.edu.au/esploro/outputs/9921860178101341/filesAndLinks?institution=61RMIT_INST\&index=null

Norden, P. (2011). Ned Kelly, John Barry and the role of social activism in criminal justice reform: Excerpts from the 2010 John Barry memorial lecture. Australian and New Zealand Journal of Criminology, 44(1), 143-150. https://doi.org/10.1177/0004865810393103

Document Version: Accepted Manuscript

Published Version: https://doi.org/10.1177/0004865810393103

Repository homepage: https://researchrepository.rmit.edu.au

(C) The Author(s) 2011

Downloaded On 2023/04/26 22:11:21 +1000

Please do not remove this page 
Thank you for downloading this document from the RMIT Research Repository.

The RMIT Research Repository is an open access database showcasing the research outputs of RMIT University researchers.

RMIT Research Repository: http://researchbank.rmit.edu.au/

\section{Citation:}

Norden, P 2011, 'Ned Kelly, John Barry and the role of social activism in criminal justice reform: Excerpts from the 2010 John Barry memorial lecture', Australian and New Zealand Journal of Criminology, vol. 44, no. 1, pp. 143-150.

See this record in the RMIT Research Repository at:

https://researchbank.rmit.edu.au/view/rmit:38288

Version: Accepted Manuscript

Copyright Statement: (C) The Author(s) 2011

Link to Published Version:

http://dx.doi.org/10.1177/0004865810393103 
Ned Kelly, John Barry and the role of social activism in criminal justice reform:

Excerpts from the 2010 John Barry Memorial Lecture

\author{
Peter Norden \\ Vice Chancellor's Fellow, University of Melbourne, Australia.
}

Printed in the Australian \& New Zealand Journal of Criminology 2011 44(1) 143-150

\begin{abstract}
This public lecture, presented on the $130^{\text {th }}$ Anniversary of the execution of Ned Kelly, each year commemorates the contribution made to the field of criminology by the late Mr Justice Barry, of the Supreme Court of Victoria. Using the heuristic method of social research, it examines the place of social activism in the field of criminal justice reform. The paper was presented on the eve of a Victorian State election, where debate about law and order issues predominated, as has occurred in many States and Territories around Australia in recent years. The author calls for a substantial review of the operation and effectiveness of the Australian criminal justice system.
\end{abstract}

\title{
Keywords
}

Activism, crime, police, prison, reform

On this day, 11 November 1880, Ned Kelly was hanged from the gallows of the Old Melbourne Gaol. Five thousand stood outside in protest, a sizeable crowd given the population of Melbourne 130 years ago was only 280,000. Close to 50,000 signatures were attached to the Petition of Mercy that was submitted to the Executive Council.

The invitation to present this John Barry memorial lecture on the $130^{\text {th }}$ anniversary of the execution of Ned Kelly encouraged me to share something of my own journey and some of the lessons learnt from my own exposure to the Australian criminal justice system.

I have set the focus of my address this evening on the role of activism in criminal justice reform.

\section{Heuristic research}

I wish to present two scenarios from my prior engagement with the Australian criminal justice system that are representative of the need for a systemic change in our nation's approach to crime. Both of these experiences reinforced in my own mind the need to maintain an activist defence of human rights and civil liberties and to contribute to a more productive formulation of criminal justice policy and practice. 
I have undertaken much of this analysis according to what has been identified as 'heuristic research'. Moustakas (1990:12) describes 'heuristic research' as involving ‘self-search, selfdialogue, and self-discovery'. He suggests 'the research question and the methodology flow out of inner awareness, meaning and inspiration'. In this heuristic process, I have been, 'personally involved in working through these key experiences of the past, searching for qualities, conditions and relationships that underlie a fundamental question, issue or concern' (Moustakas, 1990:11).

Following this analysis, I address the current challenges faced by State and Territory governments around Australia in finding more effective solutions to breaches of the criminal law in order to shape a more cohesive, inclusive, and, in essence, a safer community.

The first scenario is the shooting deaths of dozens of Victorians by police.

\section{Police use of deadly force}

Police Shootings in Victoria 1987-1989: You Deserve to Know the Truth. This was the title of a book written by the families of Mark Militano, Graeme Jensen and Jedd Houghton, with the support of the legal staff from the Flemington-Kensington Community Legal Centre and published by Fitzroy Legal Services in 1992 (Flemington/Kensington Legal Centre, 1992). In total 11 men had been shot dead by Victorian police officers over the previous two years. In the foreword to that publication, I wrote: 'The suspicion that revenge has been allowed to overcome reason, following the tragic Walsh Street killings, must be answered'. Two Victorian police officers were subsequently charged with the murder of Gary Abdullah, but the case did not proceed to trial because of lack of independent witnesses.

Militano, Jensen and Houghton were three of the young men who had been killed by police, the first two in relation to suspected armed robberies that occurred in Melbourne in the mid1980s and Houghton as part of the investigation following the tragic killing of two young police constables, Tynan and Eyre, in Walsh Street Prahran on 12 October 1988. The number of deaths as a result of police shootings continued to rise over the following years. Between January and May 1994, there were seven deaths as a result of the use of firearms by members of the Victorian Police Force. How could this be explained given that in New South Wales, with a similar population and similar patterns of criminal behaviour, there had been only a fraction of this number of deaths resulting from police shootings over the same period of time?

My explanation at the time was that the deaths followed from some particularly difficult circumstances in Victoria in the preceding years. On 27 March 1986, a bomb exploded outside the then Police Headquarters in Russell Street. Tragically a young police woman was killed and many others were injured. It was only two years later that the lives of the two young constables were tragically taken in the Walsh Street murders. It is my belief that these two major incidents helped to change the culture within the Victorian Police Force. A sense of siege was allowed to develop and in infiltrate the police training academy and the way in which all police officers were instructed to respond to a threat of violence in the coming years.

During the late 1980's and early 1990s, whenever an operational member of the police was confronted with a citizen threatening them with any sort of weapon, be it a gun, knife or baseball bat, it was the formal practice to extend a warning to the person to drop the weapon. If the person failed to do so, it was standard practice in Victoria to shoot several times to the central body of the person posing the threat, in order to remove that threat. This training 
practice was implemented officially by the Police Training Academy and resulted in the large number of persons killed.

The general public did not have a lot of sympathy with the interests of persons committing serious crimes like armed robbery. But in the early 1990s, a growing number of citizens shot dead by Victoria Police were those without a criminal record, but were distinguished by their suffering from serious mental illness.

The critical death that helped to change this deadly policy in Victoria was that of Colleen Richman, who was shot at Hanover Welfare Services in St Kilda on 23 September 1994. Richman, who had been taken from her mother's hospital bed in Adelaide when she was born as part of the Stolen Generation policy of assimilation, according to police was going berserk. They shot her four times. Hers was the $22^{\text {nd }}$ police shooting in Victoria since 1988, compared with just four in NSW in the same period. Up until that untimely death, the Victorian Police Minister, Pat McNamara, defended the police's right to use firearms to protect themselves. His position was:

Under no circumstances should police have to fear for their lives, even though using a firearm is the last resort to stop offenders. In a life-threatening situation, police are trained to aim for the main body mass, which is the torso. It is a fact of life that in a number of instances this will be fatal. (The Age, 28 March, 1994)

I conducted the memorial services for Colleen Richman. Following the service, more than 200 people joined a march down Fitzroy Street, to a protest rally at Catani Gardens, on the St Kilda foreshore. As I joined the marchers down Fitzroy Street, I received a phone call from the then Police Minister, and Deputy State Premier, Pat McNamara. This Minister admitted that police training and skills were inadequate and informed me that the government had taken the decision that day to retrain the police force in the use of firearms within six months. A new set of guidelines were produced that required Victorian police to avoid confrontation and to use only minimal force. It had taken several years and too many deaths. It had finally been established that the number one priority of Victorian Police members should be the protection of human life. Following this, the death toll resulting from police shootings in Victoria dropped dramatically to less than one a year and remained that way for more than ten years.

But the whole country was shocked when, in early December 2008, a 15-year-old boy was shot dead by four Victorian Police Officers outside Northland Shopping Centre. He was emotionally disturbed and had armed himself with two knives stolen minutes before from a local supermarket. The senior Victoria Police representatives immediately reported at the time that the officers had no other option than to fire 10 bullets at this disturbed young man. Most reasonable Australians knew intuitively that there had to be a better way. The Chief Commissioner of Victoria Police, Simon Overland, directed a serious review of police strategies, which re-emphasized the priority of securing a situation and protecting human life. This was the insight of Project Beacon more than 15 years before.

How had the Victorian community allowed these deaths to occur? The lack of public scrutiny and community accountability seem to be the explanation.

\section{High security regimes}

The second scenario focuses on high security, supermax, prison regimes. 
For many, many years, H-Division was the section of Pentridge Prison with the harshest discipline. It was the punishment and isolation block for those who had escaped and those who had seriously breached prison regulations.

H-Division was a world within a world, and the staff were the hard men of the prison service. Whenever a new prisoner arrived, he was confronted with what was known as 'the reception biff'. Surrounded by several officers, he was stripped naked and then subjected to a series of physical blows until he fell to the ground. During this time, the heavy door of the division was closed to prevent any observation of this serious breach of prison regulations. The division was reserved for any prisoner who breached the prison regulations, but his first experience upon arrival was to be the victim of a serious assault by those whose task it was to uphold the law. This practice continued until the Pentridge prison closure in 1997. The reality of the brutalizing effect of this systematic bashing by prison guards was accurately portrayed in the play, Everynight Everynight by Ray Mooney (1985). That play showed how a young offender in the person of Christopher Dale Flannery was the subject of such treatment. Flannery would in later years take revenge via his violent behaviour towards others, which earned him the title 'Mr Rentakill'.

Father Brosnan, my predecessor as Chaplain at Pentridge, used to say that the systematic brutality in H-Division had turned bike thieves into murderers. But as Mooney's play depicted, there was never an independent witness present to observe these proceedings only the closed group of H-Division officers and individual inmates. Every week as I visited that section I observed the battered faces of those newly 'welcomed' into H-Division. The official account was that they had fallen over, or had attempted to assault an officer.

In July 1980, a new maximum security division was opened within the Pentridge grounds, called 'Jika Jika' a name derived from three Aboriginal leaders in the early years of European settlement. Jika Jika maximum security section cost $\$ 7$ million to construct and was of a modern design, mostly concrete and razor ribbon wire and with much gadgetry. The prison made extensive use of electronic surveillance and all doors were remotely controlled using compressed air. No two consecutive doors could be opened at the same time, and movement through the units was carefully monitored from the central control room by radio and video cameras. The unit was awarded the 'excellence in concrete' award in 1979 by the Concrete Institute of Australia.

It did not take long for the prisoners and the staff of Jika Jika to recognize the shortcomings of both the regime and the physical environment and to become aware of its impact on human behaviour and the health of those living and working there. Despite the modern design and air reticulation and natural lighting, it was soon recognised as a far more repressive regime than the dark dungeons of $\mathrm{H}$-Division that it was intended to replace. As those who lived there were quick to point out: H-Division was run by physical brutality. Like its equivalent in New South Wales, Katingal, Jika Jika played with people’s minds.

Those who were assigned as inmates to Jika Jika were always told by the Classification Committee that if they cooperated, kept the rules and regulations and did what was asked of them, they would eventually be returned to mainstream maximum security prison life, outside of Jika Jika. There were, of course, some long-term prisoners assigned there who were serving long periods of imprisonment. After more than 12 months in Jika Jika, most prisoners would have preferred to be back in the notorious H-Division.

One group of five prisoners had been given the following instructions on more than one occasion: 'Toe the line for the next 12 months and you will be moved back to the 
mainstream'. The 12 months came with no change to their classification. They felt that they were being buried in Jika Jika, with absolutely no sign that there would ever be a change. The previous December, as prison chaplain I had written to the Prisons Minister, the late Jim Kennan, asking for one of this group of five, Robert Wright, to be moved from Jika Jika to BDivision, another high security area. Wright had been in Jika Jika for more than six years. My concerns were expressed to the responsible Government Minister in these terms:

I believe it is unjust to hold Wright any longer in Jika. Other prisoners have escaped from that Division. Other prisoners have committed equally as serious crimes. No other prisoners has been held in that Division as long as Robert Wright has at this time. I have made personal representations to you previously about the brutalizing effect of long-term placement in Jika.

But I was given no indication when, if ever, Wright would be moved. In October 1987, Wright and four other prisoners barricaded themselves in their six man unit and set fire to newspapers and other materials they had stored over some weeks. The prison officers failed to break their way into the strongly barricaded unit, and the five men died of smoke asphyxiation with less than 30 minutes.

The government had been warned. The regime that had operated in the Jika Jika section could never have been sustained. The government inaction in relation to such representations was reprehensible. As a result of the public alarm about the deaths and the saturation media coverage, the Prisons Minister announced within a few days that Jika Jika would be closed and the inmates moved to other sections of Pentridge and other Victorian prisons. In doing so, he himself criticized the regime there, and referred to it as 'an electronic zoo'. It was a shame he failed to act earlier.

The State Coroner, Hal Hallenstein, reported on the investigation into the deaths and the fire in Jika Jika two years later. In his conclusions to that Coronial Inquiry, he stated:

The ultimate failure of the Office of Corrections in this case lies in its own hierarchical, ineffectual and moribund administration. The Office of Corrections also failed to have available a planned, swift, practiced, and certain methods of breaching a barricaded door in circumstances where the events of barricade and fire had been reasonable foreseeable and warned of... If one looks at prison administration....with respect to this fire, one finds ineptitude, failure and non-performance in almost every aspect of the events examined. In this case, the prison administration is seen to be in a state of general collapse.

The conduct of the Office of Corrections in this case raised deep and fundamental concern for our community's free institutions and its democratic style. In this inquest the Office of Corrections has sought to be unaccountable. It is recommended that there be an independent and general public inquiry into the Office of Corrections and its administration of the prison system in Victoria. (Hallenstein, 1989: 71-72)

This inquiry was undertaken by a retired Supreme Court Judge, Justice Murray, who tabled his report in State Parliament on 7 March 1990. It is my view that the Murray Report failed to deal with the serious issues that the Coroner had raised. The political heat had gone from the issue and the Murray Inquiry was seen as burying the issue, once and for all.

But Bree Carlton (2007) undertook a comprehensive and critical analysis of the Jika Jika tragedy. She explained that she was 'motivated by a desire to resurrect and reconstruct the Jika experience in order to recognize past injustices and circumvent the continuing proliferation of harm and violence producing prison regimes in the present' (Carlton, 2007:8) 
When the Jika Jika high security unit was opened in 1980, the correctional services brochure announced that: 'It has been designed to meet community expectations of the secure detention of dangerous offenders and the provision of human containment for such persons'. But events clearly underscore the conclusion that it was an expensive failure. You cannot use terms like 'humane containment' and in your policies and procedures fail to recognize the importance of treating people, even high security prisoners, as real people.

\section{Criminological discourse}

The famous criminologist, Stanley Cohen, more than 20 years ago explained that social control system work is accompanied by much talk.

(These) good stories stand for or signify what the system likes to think it is doing, justify or rationalise what it has already done and indicate what it would like to be doing, if only given the chance and the resources. This talk also has other functions: to maintain and increase the self-confidence, worth and interests of those who work in the system, to protect them from criticism and to suggest that they are doing alright in a difficult world. (Cohen, 1985:157)

Cohen suggested that the new words used, like corrections, might bear only the most oblique relationship to what is actually happening in the cells, buildings, corridors, offices and encounters of the social control apparatus, in other words the prisons and so called correctional programmes.

More recently, David Garland (1990: 180) developed this same theme when he explained:

The current rules of political engagement ensure that governments and legislatures are highly attuned to pubic concerns, particularly to the sentiment that offenders are being insufficiently punished or dangerous individuals inadequately controlled, and there is a great pressure to enact measures that express and relive these concerns.

Garland further explained that the chief aims of the criminal justice system are not at all about correction, but 'to assuage popular outrage, reassure the public, and restore the credibility of the system, all of which are political rather than penological concerns'.

Examining the experiences that I have outlined in the above scenarios, one is led to ask serious questions about the real purposes of such ineffective criminological policies and practices.

\section{The present political climate}

Governments around Australia face a critical challenge in seeking to shape a more effective criminal justice policy. Throughout the country, State and Territory elections highlight law and order issues as pre-eminent and promise increased expenditure on police and prison construction. More than 30 years' experience in monitoring criminal justice policy has told me that there is little to be gained from a bidding war on who could be tougher on law and order, other than purely political advantage. Good social policy can never evolve in this way. Do we as a nation seriously believe that the increased incarceration of young adult males from the most disadvantaged communities in Australia will result in anything more than a hardened criminal subculture in those neighbourhoods?

\section{The way forward}

There is a need to take a different approach. 
Over the last 10 years, I project managed research which Professor Tony Vinson undertook mapping the concentration of disadvantage by postcode for every part of Australia (Vinson, 2007). More than 20 measures of disadvantage were used, including court conviction and imprisonment, in addition to the regular measurements used by the Australian Bureau of Statistics SEIFA scale, such as income, education, employment and housing.

A clear pattern of correlation was identified mapping every postcode area in Australia, linking high rates of court convictions and imprisonment for those areas that have high levels of early school leaving, lack of further education and training after leaving school, high levels of unemployment and poor levels of mental health.

The result, Vinson reports, is that the most disadvantaged communities around Australia, in metropolitan, regional and rural areas are being more and more deeply mined by the instrumentalities of the criminal justice system. We see the impact of this most clearly when we refer to the overrepresentation of our Australian Indigenous community within prison populations. But the problem is not limited to our Indigenous brothers and sisters...it is the same pattern for every severely disadvantaged community in Australia.

Addressing such entrenched long-term disadvantage does not rest with the criminal justice system. It is the criminal justice system that is left to pick up the casualties when our other social systems have failed us. What is necessary to produce lasting change are carefully planned, collaborative, long-term, multi-disciplinary interventions in the most disadvantaged communities that seek to bring about real participation and empowerment. Within Australia, similar analyses and recommendations have been made for many years (Brown, 1994; Henry and Lane, 2004).

\section{Conclusion}

In concluding these reflections and this call for a more rational, evidence-based policy direction for the future of the Australian criminal justice system today, I believe it is critical that we acknowledge the limitations of our present systems and our need for a substantial change of direction.

Similar calls have been made in recent times by US Senator Jim Webb (Webb, 2009) in a country that has 5 per cent of the world's population, but 25 per cent of the reported prison population. The Open Society Institute in Washington DC (Beane, 2008) also calls for multidisciplinary collaboration in responding to the issues that fuel the cycle of incarceration.

I look to the future generation of lawyers, academics, social activists and community organizers to consider that challenge, one that should never be left in the hands of our political representatives.

\section{References}

Beane C (2008) Moving Towards a More Integrative Approach to Justice Reform. Washington DC: Open Society Institute.

Brown D (1994) Transcending dichotomies: The criminal justice network and a dialogue concerning prisoners and victims. Current Issues in Criminal Justice 6(1): 143.

Carlton B (2007) Imprisoning resistance: Life and death in an Australian supermax. Sydney Institute of Criminology Series, No 25. 
Cohen S (1985) Visions of Social Contro. Cambridge: Policy Press.

Flemington/Kensington Legal Centre (1992) Police Shootings in Victoria 1987-1989: You Deserve to Know the Truth. Melbourne: Fitzroy Legal Service.

Garland D (1990) Punishment and Modern Society: A Study in Social Theory. Oxford: Oxford University Press.

Garland D (2001) Culture of Control: Crime and Social Order in Contemporary Society. Chicago: University of Chicago Press.

Hallenstein H (1989) Record of Investigation into Death and Fire. State Coroner of Victoria Report, Cases 4771-5.

Henry K and Lane M (2004) Beyond symptoms: Crime prevention and community development. Australian Journal of Social Issues 39: 201-213.

Mooney R (1985) Everynight, Everynight. Melbourne: Yackandandah Publications.

Moustakas C (1990) Heuristic Research: Design, Methodology and Applications. London: Sage.

Vinson A (2007) Dropping Off The Edge. Melbourne: Jesuit Social Services.

Webb J (2009) Now is the time to reform our criminal justice system. Criminal Justice Ethics 28 (2): 163-167. 